\title{
ELEPHANTS AND ELECTRIC FENCES
}

\author{
By J. A. Hislop \\ Game Warden, Malaya
}

Although the electric fence has been proved a successful
deterrent to crop-raiding deer, pig, gaur and other wild animals,
I hesitate to sing its praises against elephant.

I had experience of three such fences in Malaya over a period of six or seven years. The first was a long fence of two wires round the edge of an extensive new plantation which, until felling took place, had been a haunt of elepliant from time immemorial. At one end of the clearing a ditch twelve or more feet wide and six to eight feet deep had been dug, with the intention both of draining the land and of acting as an additional elephant barrier. It served the first purpose admirably but the elephants slid down into the ditch and climbed up the other side, where they could examine the fence at leisure. After a short time they breached it regularly, although there was no overhead forest to interfere with it and the ground was naturally swampy, making for good electrical contact. The other part of this fence was along the edge of the jungle and regularly patrolled, but it too was frequently broken down.

The second fence completely surrounded about fifty acres of young rubber. It was kept clear of undergrowth, patrolled every morning and evening and in as good condition as could be. It stood without damage for about four years, and then suddenly it was breached, a small herd gaining entry one night and causing considerable damage. That proved to be the beginning of the end. The fence was never again of any use, and the greater part of the young rubber was completely destroyed in a succession of visitations during the next two years.

Why this fence was broken through is not at all clear. The current had been checked the previous evening and an investigation next day produced no evidence of accidental shorting of the electric current by fallen branches or anything else. It was however discovered that there were one or two small elephant calves with the herd. Perhaps one of them got in beneath the fence and its squeal of fright as it touched the wire on the way out, brought it's mother barging in to its help. 'Thus she may have learned that the fence was not dangerous after all.

The third fence was around a hundred acre clearing in flat land by a river. It also was well kept and regularly patrolled 
and it remained undamaged for about two years. Then it was breached in some fifteen places by a fairly large elephant herd and was never again effective.

I have no adequate explanation of all this but I have yet to see an electric fence which is regularly visited by a herd of elephants and keeps them out with certainty.

The above article was suggested by experiments in electric fencing now being carried out in Tanganyika.

Mr. E. O. Shebbeare comments as follows :-

I am surprised that my friend Mr. J. A. Hislop finds electric fences of little use against elephant in Malaya. As a game warden there before the war I found them quite effective, but animals are quick to adapt themselves to novelties.

My experience of electric fences, short though it was, prompts me to offer a few suggestions :-

The Posts.-The most common fault in all types of fences is to use too many and too weak posts. For good posts 30 feet spacing is not too wide. "Good" means round timber not less than 6 inches in diameter or square not less than 5 by 5 inches. Angle iron may have to be used where no timber can be had, but it is a great temptation to elephants who cannot resist tying it into knots. Sound growing trees are perfect but are not worth sacrificing alignment or spacing.

The Insulators. - We tried several makes which differed little except in price. If the "cotton-reel" pattern is used, do not take a turn of the live wire round the insulator but bind it on with a separate piece of wire. (Sec under "Tension" below).

The Wire.-You can confine pigs or cows to a corner of your paddock with a single live strand 18 inches above ground. How many live strands you will need in an electrified game-proof fence depends on what linds of game you want to keep out; if it is mouse-decr and clephant you will need more than one. Unless it is a special problem limited to one or two species, a more practical plan which may cost less in the end, is to combine a good ordinary game-proof fence, with a single live strand to stop elephants. "Good" here means something as strong as the following, reading from the bottom upwards :-First, 42 inches deep of "wove wire" (chain link) preferably point-welded, or where wild pigs are a nuisance, 48 inches with 6 inches buried underground. Next a single strand of barbed wire 1 foot above the top of the wove-wire, and lastly another strand of barbed wire 18 inches higher still and therefore six feet above the ground. This last strand of barbed wire (or both if desired) can be "live". 
Tension.-The ideal for an ordinary fence-" every wire like a banjo-string "- does not hold for "live" strands, which should be able to give a little in an emergency or heavy animals may snap them. Elephants sometimes, and gaur often, plunge forward on feeling the shock. Just before our work was interrupted by the threat of invasion, we were experimenting with a live wire which ran freely through the insulators and was kept taut by strong spiral springs at intervals.

Cleared Path. - A path on the outside of the fence is necessary for inspection and the wider this is cleared the less likely is it that jungle will get pushed over the wire; a clearing equal in width to the height of the surrounding trees has been advocated but appears quite unnecessary, at least in Malaya.

Dry Ground.-We had no experience of working in really dry country but, after a long drought, for Malaya, we noticed that the gaur, though not the elephants, seemed less sensitive to shock and we thought that this might be due to their hoofs making poor electrical contact with very dry ground. We were about to experiment with a pair of " live" and " earthed " wires insulated from, but fixed close to one another, but the drought did not last long enough for us to try it.

"Flags".-White rags tied to the live wire to make it conspicuous seemed to have some psychological effect on gaur which, on onc occasion, kept well away from the flagged fence after one of their number had been shocked. Flags seemed to have less effect, or none, against elephants.

General.-When installing an clectric fence a common mistake is, after spending money on the set, batteries, wires and insulators, to render them all useless by economising over fence posts and inspection. If you erect an electric fence, it must be somebody's paid job to walk round it once a day.

Mr. A. H. Fetherstonhaugh, until recently Chief Game Warden of the Federation of Malaya, writes as follows :-

I am in broad agrecment with Mr. Shebbeare. Most of my experience was gained when carrying out the experiments which he mentions and I have had no hesitation in recommending electrified fences for protecting rubber estates from wild animals.

I do not wish to suggest that these fences are the panacea for all ills, particularly where elephants are concerned. We found that range, incidence and distribution of fodder and in a lesser degree topography, had a marked bearing upon the problem and each case had to be treated individually. An extreme case was where a herd of about 18 elephants had to be excluded from 
an area being opened up for an irrigation scheme. The herd lived in a relatively circumscribed area giving limited range and the most attractive feeding was in the swamps and scrub country carmarked for the scheme. We tried everything we could think of, but nothing would keep them out and even the progressive disappearance of the natural fodder had no appreciable effect. We had to shoot them.

Nothing would put a permanent stop to elephants following their regular migration route, unless it was the development of the land to an extent which completely obliterated natural features over a wide area. A classic example was on a rubber estate where everything had been tried in an effort to close such a route and in the end the manager left a strip on either side of the elephant path unplanted. Damage then became negligible.

We did have minor trouble with fence posts being pulled up but found that barbed wire wound round them usually had the desired effect. The size and sagacity of elephants made them a tough proposition but provided that they had sufficient range, adequate fodder and that a major migration route was not involved, we could claim considerable success; but there is plenty of scope for further experiment with electrified fencing.

Ed. Note:-

The Planters' Bulletin for November, 1952, contains an article, with diagrams, on this subject by Mr. Fetherstonhaugh. 